\title{
Ubiquitin Fusion System for Recombinant Peptide Expression and Purification: Application to the Cytoplasmic Domain of Syndecan-4
}

\author{
Young Kee Chae, Hayan Lee, ${ }^{\dagger+}$ and Weontae Lee ${ }^{\ddagger+*}$ \\ ${ }^{\dagger}$ Department of Chemistry and Recombinant Protein Expression Center, Sejong Lniversitw, Seoul 143-747, Korea \\ ${ }^{\dagger}$ Department of Biochemistry and HTSD-NhR \& Application NRL, Yonsei Lninersitw, Seoul 120-7+9, Korea \\ ${ }^{*}$ E-mail: wlee âspin.yonsei.ac.kr \\ Received Jume 25, 2007
}

\begin{abstract}
The cytoplasmic domain of syndecan-4. a type I transmembrane heparan sulfate proteoglycan. was overexpressed as a fised form with the ubiquitin molecule in Escherichia coli. and the fusion protein was purified using immobilized metal affinity chromatography (IMAC). The cytoplasmic domain was released from its fusion partner bỵ using ỵeast ubiquitin hydrolase (YUH). and subsequently purified by reverse phase chromatography. The integrity of the resulting peptide fragment was checked by MALDI-TOF and NMR spectroscopy. The yield of the peptide was 3.0-1.5 mg per liter in LB or minimal medium. respectively. The recombinant expression and purification of this domain will enable us its structural and functional studies using multidimensional NMR spectroscopy
\end{abstract}

Key Words : Ubiquitin fusion, Syndecan-4. MALDI-TOF, NMR

\section{Introduction}

The syndecans belong to a family of ty'pe I transmembrane heparan sulfate proteoglycan (HSPG), and they play an important role in the regulation of various cellular processes. ${ }^{1-3}$ Four types of mammalian syndecans have been reported so far. Among these syndecan-4 is believed to play a critical role in the assembly of focal adhesions with microfilament bundles. ${ }^{4.5}$ For example. fibronectin (FN) interacts with $\beta 1$ integrins and syndecan- 4 which are the cell-surface receptors. ${ }^{3-5}$ During initial cell attachment and spreading. $\beta 1$ integrins primarily regulate the cell adhesion. but later on. the binding of FN with syndecan-4 is an essential step for the assembly of focal adhesions and actin stress fibers. ${ }^{4.5}$

There are three distinct regions in the cytoplasmic domain of syndecans. ${ }^{3} \mathrm{Cl}$ region lies right next to the transmembrane domain. then the $\mathrm{V}$ region. and the $\mathrm{C} 2$ region is at the carbosy terminus. The $\mathrm{C} 1$ and $\mathrm{C} 2$ regions are highly homologous. The $\mathrm{C} 2$ region of all four mammalian syrndecans can interact with several PDZ domain-containing proteins like syntenin. ${ }^{6} \mathrm{CASK}^{7}$ or GIPC (synectiv/ SEMCAP-1). ${ }^{\S}$ These interactions may play a role in trafficking and/or establishing networks of submembranous signaling complexes. ${ }^{9.11}$ The $\mathrm{V}$ region. flanked by $\mathrm{Cl}$ and $\mathrm{C} 2$ domains, is unique to each syndecan. The $\mathrm{V}$ region of syndecan-4 can interact with phosphatidylinositol 4.5 bisphosphate $\left(\mathrm{PIP}_{2}\right)$ and the catalytic domain of the protein kinase $\mathrm{C} \alpha^{11-15}$

The three dimensional structures of the cytoplasmic domain of syndecan-4 were solved by NMR spectroscopy. ${ }^{16.17}$ However it would be much more meaningful if the structure of the whole complex is known. To get the complex structure a large amount of sample is needed. and for NMR spectroscopy it also needs to be labeled. which requires the recombinant expression of the peptide in a suitable host. Here we present our method of producing and purifying recombinant cytoplasmic domain of syndecan-4 by using the ubiquitin fusion șistem in Escherichia coli.

\section{Materials and Methods}

Construction of the $4 \mathrm{~L}$ expression plasmid with (His) $6_{-}$ tagged ubiquitin as a fusion partner. The gene coding for $4 \mathrm{~L}$ was chemically synthesized by CoreBio. Inc. (Seoul. Korea). The amino acid sequence of $4 \mathrm{~L}$ is RMKKKDEGSY DLGKKPIYKK APTNEFYA (28mer), and the nucleotide sequence was obtained by reverse translation. The sense strand (93mer) was 5'- gat ccc gca tga aga aga agg atg aag gca gtt acg act tgg gca aga aac cca tct aca aaa aag ccc cca cca acg agt tct acg cat gac $-3^{\prime}$. and the antisense (93mer). $5^{\prime}-\mathrm{tcg}$ agt cat gcg tag aac tcg ttg gtg ggg gct ttt ttg tag atg ggt ttc ttg ccc aag tcg taa ctg cct tca tcc ttc ttc ttc atg cgg -3'. Two strands were annealed by heating at $95^{\circ} \mathrm{C}$ for $5 \mathrm{~min}$, and slowly cooling down to the ambient temperature. Upon annealing. the $\mathrm{N}$ - and $\mathrm{C}$-termini became compatible with BamHI and SalI ends respectively. The plasmid pET-28a/ $\mathrm{ubi}^{18}$ was digested with BamHI and SalI. purified and ligated with the synthetic syndecan $4 \mathrm{~L}$ gene. The resulting plasmid was named $\mathrm{pET}-28 \mathrm{a} / \mathrm{ubi} / 4 \mathrm{~L}$ (Fig. 1).

Expression and purification of ubiquitin-4L fusion protein from an LB medium. The $\mathrm{pET}-28 \mathrm{a} / \mathrm{ubi} / 4 \mathrm{~L}$ plasmid was brought into the expression host. Rosetta(DE3)pLys (Novagen, Madison. WI). One colony was used to inoculate a $100 \mathrm{~mL}$ LB medium supplemented with $50 \mu \mathrm{g} / \mathrm{mL}$ kanamycin and $34 \mu \mathrm{g} / \mathrm{mL}$ chloramphenicol. and grown overnight in a $37^{\circ} \mathrm{C}$ shaking incubator. The fully grown culture was mixed with a fresh one liter LB medium with the same antibiotics cocktail the next morning. The culture was grown at $37^{\circ} \mathrm{C}$. and IPTG was added to a final concentration 


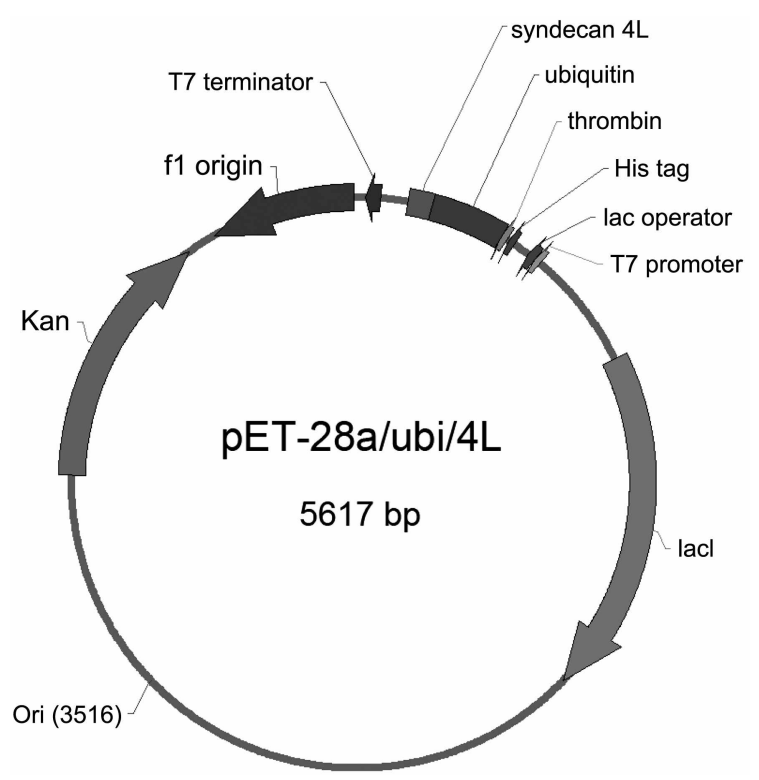

Figure I. Plasmid vector map of pl:"1-28ablubi/41..

of $0.5 \mathrm{mM}$ when the $\mathrm{OD}_{6,61}$ reached 1.0 . The culture was harvested 5 hours later and the cells were resuspended in 30 $\mathrm{mL}$ of $10 \mathrm{mM}$ [ris $\mathrm{HCl} \mathrm{pH} 8.0$. The cells were lysed by freeze-and-thaw and the DNA was fragmented by ultrasonication. The soluble fraction was retained after centrifugation at 15,000 rpm for $20 \mathrm{~min}$, and loaded onto Hi [rap Chelating $\mathrm{H}^{2}$ column $(5 \mathrm{~mL})$. The column was put on the $\mathrm{AK}$ 'TA Prime system (GE Healthcare, Piscataway, NJ, USA), and imidazole gradient of 0 to $0.4 \mathrm{M}$ was applied. The fractions containing ubiquitin-4L were collected and pooled into one tube. The amount of protein in the pooled fractions was measured by using Protein Assay kit (Bio-Rad, Hercules, CA, USA).

Expression and purification of ubiquitin-4L fusion protein from a minimal medium. Rosetta( $D E 3)$ pLys $S$ containing the $\mathrm{pE}\left[-28 \mathrm{a}\right.$ ubi/4L was grown at $37^{\circ} \mathrm{C}$ in a 5 $\mathrm{mL} \mathrm{LB}$ medium inoculated from a single colony. I $\mathrm{mL}$ of the fully grown culture was mixed with $100 \mathrm{~mL}$ of the minimal medium and grown overnight at $37^{\circ} \mathrm{C}$. The fully grown culture was mixed with a 0.9 liter minimal medium and the culture was grown at $37^{\circ} \mathrm{C}$. For the uniform $\left[{ }^{15} \mathrm{~N}\right]$ labeling. $0.1 \mathrm{~g}$ of ${ }^{15} \mathrm{NH}_{4} \mathrm{Cl}$ was provided as a sole nitrogen source for $100 \mathrm{~mL}$ culture. The production and purification steps were the same as the previous section

Purification of $4 \mathrm{~L}$. To the purified ubiquitin- $4 \mathrm{~L}$ fusion protein. $\beta$-mercaptoethanol and $\mathrm{YUH}$ were added to the final concentrations of $1 \mathrm{mM}$ and $2 \mathrm{mg} / \mathrm{mL}$, respectively. The mixture was incubated at $37^{\circ} \mathrm{C}$ for one hour. The reaction mixture was directly loaded onto a Resource $\mathrm{RPC}$. column (GE Healthcare, Piscataway, NJ, USA), and an acetonitrile gradient of 15 to $40 \%$ was applied using the AKTA Basic system. The $4 \mathrm{~L}$ fraction was pooled and lyophilized. The final product was checked by MALDI]OF. The peptide concentration of the pooled fractions was calculated from the theoretical extinction coefficient, $\varepsilon_{281}=$ $1.295(\mathrm{mg} / \mathrm{mL})^{-1} \mathrm{~cm}^{-1}$.
NMR experiments. The NMR sample contained 0.05 $\left.\mathrm{mM}\left[{ }^{15} \mathrm{~N}\right]-4\right]$. in $10 \mathrm{mM}$ sodium phosphate buffer, $\mathrm{pH} 7.0$ and $10 \% \mathrm{D}_{2} \mathrm{O}$. The ${ }^{1} \mathrm{H}_{-}{ }^{15} \mathrm{~N}$ heteronuclear single quantum coherence ( $\mathrm{HSQC}$ ) spectrum was collected at $10^{\circ} \mathrm{C}$ on a Bruker Avancell $500 \mathrm{MHz}$ spectrometer. The raw data contained 2048 and 256 complex points in $t_{2}$ and of $t_{1}$, respectively. The data was processed using NMRPipe software package. ${ }^{(4)}$ The final spectrum contained 1024 and 256 real points in $t_{2}$ and of $t_{1}$, respectively.

\section{Results and Discussion}

Construction of expression plasmids. The genes coding for YUH and ubiquitin-41. were inserted into His-Tagr containing vectors to facilitate the purification of the desired proteins. The pF:T-28a/ubi/4L, plasmid had the kanamycin resistance rather than ampicillin, and we could grow the cells for a longer period of time after the 1$]^{x}[\mathrm{G}$ induction. The ubiquitin fusion system was chosen according to the work done by Kohno et al. ${ }^{20}$ One of the most widely used fusion partner for producing proteins is the glutathione Stransferase (GSl), but the size of GS [ is $26.2 \mathrm{kDa}$, which is considerably larger than $8.5 \mathrm{kDa}$ of ubiquitin. The relatively smaller size of ubiquitin gives the advantage of higher yield of the target protein when the total expression levels of the fusion proteins are not much different.

Expression and purification of ubiquitin-4L fusion protein. The expressed proteins appeared as 3 bands whose sizes corresponded to ubiquitin alone, ubiquitin with partial $4 \mathrm{~L}$, and ubiquitin with full-sized $4 \mathrm{~L}$ as can be seen in lane 7 of Figure 2 . The band corresponding to ubiquitin with partial $4 \mathrm{~L}$ appeared to be the weakest. and the other two bands were of about the same intensity. We suspect that some protease in the $E$. coli cell was in action, and this kind of unwanted cleavage was reported in other previous studies. ${ }^{18.21}$ The purity of the fusion protein was examined by SDS-PAGE as shown in Figure 2. The yield of the fusion protein was around 24 or $15 \mathrm{mg}$ per liter of LB or minimal medium. respectively. The yield of the final peptide was $3.0-1.5 \mathrm{mg}$ per liter in LB or minimal medium, respectively. However,

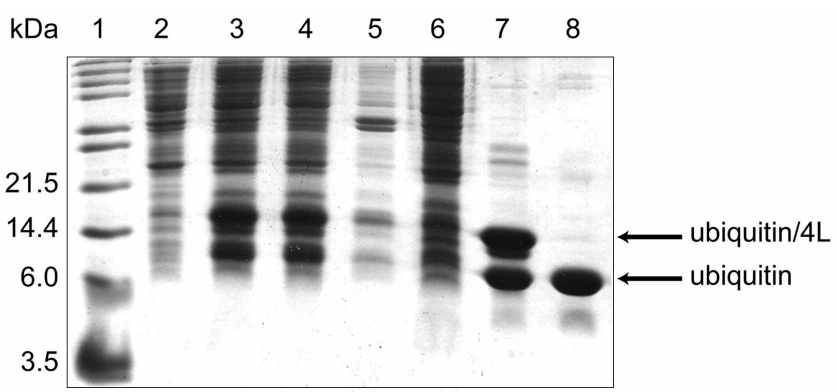

Figure 2. Purilication of syndecan 4I, produced from I liter I,B medium as monitored by $16 \%$ SDS-PAGL. Lane l, size marker; lane 2. whole bell lysate before IPTG induction: lanes 3 and 4. supematant and pellet of cell lysate. respectively: lane 5. flowthrough Iraction of supernatant from I Hil trap Chelating I IP column; lane 6 , fraction that was bound to the I Ii Trap column: lane 8 . sample of lane 7 after YUH cleavage reaction. 


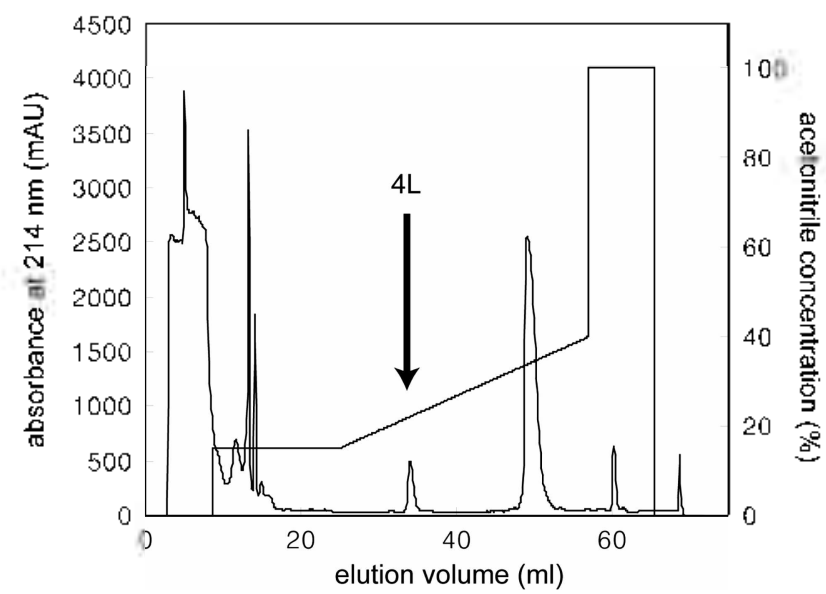

Figure 3. The elution prolile from the reverse phase chromatography. The peak corresponding to $4 \mathrm{~L}$ is marked with an arrom. The concentration of acetonitrile during the gradient clution is also shown.

this amount included not only the ubiquitin with full-sized $4 \mathrm{~L}$, but also the ubiquitin molecule alone and that with partial 4L. Thus, it would be safe to say that amount of the ubiquitin with full-sized 4L was half of the calculated mass.

Purification of $\mathbf{4 L}$. The original purification strategy was to exchange buffers from imidazole-rich to an imidazolefree state before cleaving the fusion protein by $\mathrm{YUH}$, which would help remove both of the His-tagged $\mathrm{YUH}$ and ubiquitin by filtering them through the $\mathrm{Hi}$ [rap Chelating $\mathrm{HP}^{3}$ column. However, not all of the ubiquitin molecules were filtered out, but we always found small amount of contaminating ubiquitin molecules in the flow-through fraction. Since the filtering step did not work satisfactorily, we directly added YUH and $\beta$-mercaptoethanol to the eluted fraction from the Hilrap Chelating $H P$ column without changing to the imidazole-free buffer. The prepared $\mathrm{YUH}$ was effective in cleaving ubiquitin from $4 \mathrm{~L}$. One hour was enough to cleave around $25 \mathrm{mg}$ of the fusion protein with 50 $\mu \mathrm{g}$ of YUH. Following cleavage, the entire reaction mixture was loaded onto a Resource $\mathrm{RPC}^{\mathrm{C}} \mathrm{Column}$ in $2 \mathrm{~mL}$ aliquots (GE Healthcare. Piscataway, NJ, USA). The volume of the cleavage reaction mixture was around $30 \mathrm{~mL}$, so we repeated the reverse phase chromatography step 15 times. The peptide was eluted at around $23 \%$ acetonitrile, and all the $4 \mathrm{~L}$-containing fractions were pooled and lyophilized (rig. 3 ). The final yield of $4 \mathrm{~L}$ was around 3 or $1.5 \mathrm{mg}$ per liter of LB or minimal medium, respectively. MALDI-]OF was used to verify the purified peptide (Fig. 4). MALD]-[OF showed a major peak at $3449.4 \mathrm{Da}$, which is in good agreement with the theoretical molecular weight of $3450.9 \mathrm{Da}$.

HSQC spectrum of $\mathbf{4 L}$. The HSQC spectrum showed 24 well resolved peaks (Fig. 5). Among these peaks the two around $\left({ }^{15} \mathrm{~N},{ }^{1} \mathrm{H}\right)=(113 \mathrm{ppm}, 6.95 / 7.65 \mathrm{ppm})$ were characteristic resonances of the sidechain atnide protons of Asn or Gln. There is one Asn but no Gln in 4L, so these peaks were tentatively assigned to the sidechain amide protons of Asn24, and this finding provided another assurance of the purified $4 \mathrm{~L}$.

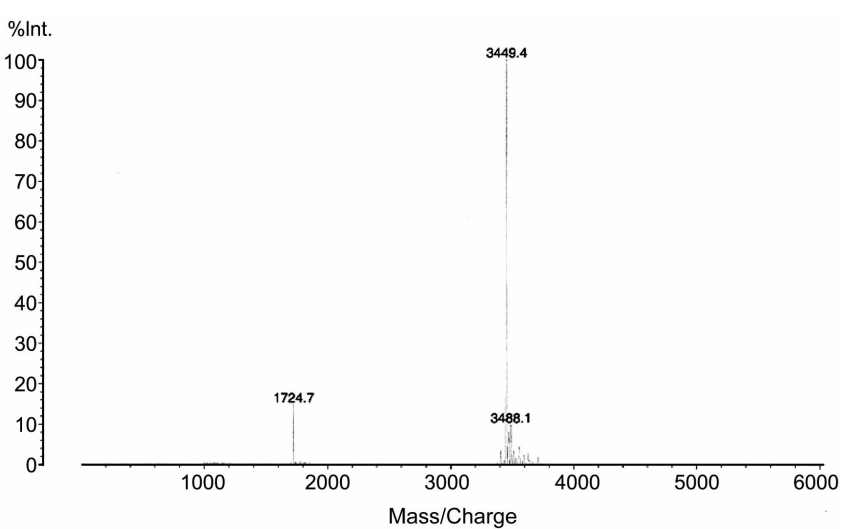

Figure 4. M $\mathrm{AI}$.I)I-TOI spectrum of purilied syndecan $4 \mathrm{I}$. Single and double charged molecular ions are seen at $m / L=3448.4$ and 1724.4. respectivily.

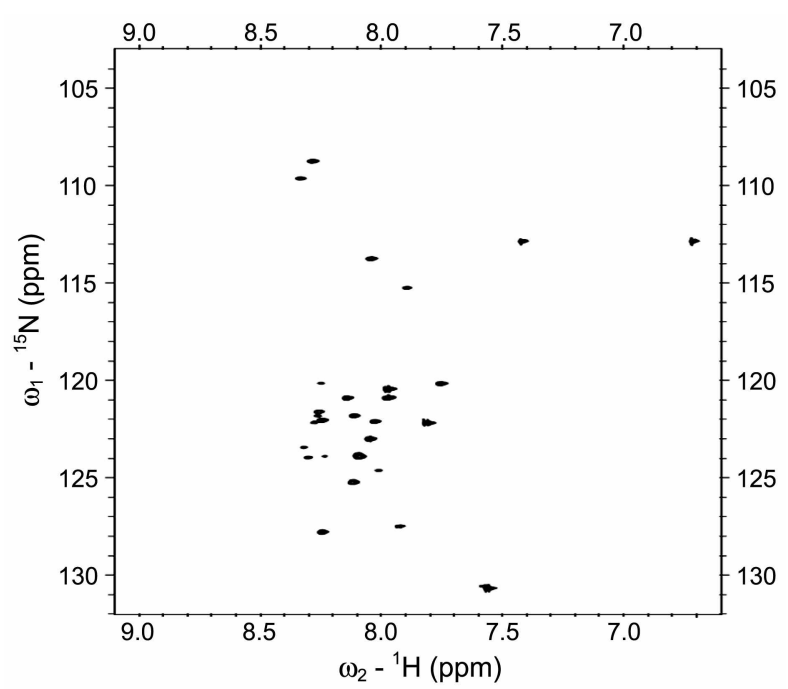

Figure 5. $\left[{ }^{1} \mathrm{H}^{15} \mathrm{NJ}\right.$ HSQC spectrum of $4 \mathrm{~L}$ recorded at $283 \mathrm{~K}$.

\section{Conclusion}

The methods in this report present a very efficient production/purification procedure for the target peptide. The ubiquitin fusion system was proven to be successful and as such to offer a competitive alternative compared to other fusion systems such as GS[ or MBP. '] This system gets maximally effective when it comes to the recombinant peptide preparation. The biggest advantage of the ubiquitin fusion system over the others stems from the small size of ubiquitin. Because it is small, the net yield of the target peptide is higher for the ubiquitin fusion system compared to the others if the fusion proteins were produced in a similar quantity. The YUH efficiently cleaved the ubiquitin fusion protein even in the high salt condition like the elution buffer of the Hilrap Chelate column, and since it can easily be prepared in the homemade fashion, it provides a costeffective way of preparing the target peptide as compared to the expensive protease like thrombin. 'The NMR and X-ray structural studies are now under way. 
Acknowledgment. This work was supported by the Korea Science and Engineering Foundation (KOSEF) through the National Research Lab Program funded by the Ministry of Science and Technology (Ml-0203-00-0020) and the KOSEF grant funded by the Korea government (MOST) (R01-2007-000-10161-0). This work was also supported in part by Brain Korea 21(BK2l) program.

\section{References}

1. Bernfield. M.: Gotte. M.: Park. P. W: Reizes. O.: Fitzgerald. M. L.: Lincecum. J.: Zako. M. Amm. Rev Biochem. 1999. 68. 729777

2. Carey D. J. Biochem. J. 1997.327, 1-16.

3. Couchman J. R.: Woods. A. J. Ce/l Sci. 1999, 112.3415-3420.

4. Woods. A.: McCarthy. I. B.: Furcht. L. T: Couchman, I. R. Mol. Biol. Cell 1993. + 605-613.

5. Saoncella. S.: Echtermeyer. F.: Denhez. F.: Nowlen. J. K.: Mosher. D. F.: Robinson. S. D.: Hynes. R. O.: Goetinck. P. F. Proc. Natl. Acad Sci. USA 1999, $96.2805-2810$.

6. Grootjans. J. I: Zimmerman, P; Reekmans, G.: Smets. A.: Degeest, G.; Durr J; David, G. Proc. Nall Acad Sci LS.A 1997. 94. $13683-13688$.

7. Hsueh. Y. P.: Yang. F. C.: Kharazia. V.: Naisbitt. S.: Cohen. A. R.: Weinberg. R. J: Sheng. M. J. Cell Biol. 1998. H2. 139-151

8. Gao, Y. Li. M. Chen. W. Simons. M. J. Cell Plysiol. 2000. 184. $373-379$
9. Grootjans. I. J.: Reekmans. G.: Ceulemans. H.: David. G. J. Biol. Chent 2000. 275. 19933-19941.

10. Zimnmermantn. P.: Tomnatis. D.: Rosas. M.: Grootjan1s. J.: Leenarts. I.: Degeest. G.: Reekmans. G: Coomans, C.: David. G. Mfol Biol Cell 2001. 12. $339-350$

11. Oh. E. S.: Woods, A.; Couchman, J. R. J. Biol. Chem. 1997. 272. $8133-8136$

12. Oh. E. S.: Woods. A.: Lim. S. T.: Theibert. A.: Couchman. T. R. J Biol. Chem. 1998.273. 10624-10629.

13. Lee. D.: Oh. E. S.: Woods, A.: Couchman. J. R.; Lee. W. J. Biol Chem. 1998, 273, 13022-13029.

14. Couchman. J. R: Vogt, S; Lim. S. T; Lim. Y.: Oh. E. S: Prestwich. G. D.: Theibett. A.: Lee. W.: Woods. A. J. Biol. Chent. 2002. 277. 49296-49303

15. Lim. S. T.: Langley. R. L.: Couchman. .T. R.: Woods. A. J. Biol. Chem. 2003, 278, $13795-13802$.

16. Shin, J.: Lee. W: Lee. D.: Koo, B. K.: Lim, Y.: Woods. A.; Couchman. J. R.: Oh. E. S. Biochemistry 2001, $40.8471-8478$.

17. Koo. B. K.: Jung. Y. S.: Shin1. T.: Han1. I.: Mortier. E. Zimmermann1. P.: Whiteford. I. R.: Couchmant. J. R.: Oh. E. S.: Lee. W. J Mol. Biol 2006. 355.651-663.

18. Moon. W. J.: Hwang. D. K.: Park, E. J.; Kim, Y. M.: Chae. Y. K Protein Exp: Purif. 2007, 51. 141-146.

19. Delaglio, F: Grzesiek, S.: Vuister, G. W.: Zhu, G.: Pfeifer. J; Bax. A. J. Bionol. M R 1995. 6.277-293.

20. Kohn1o. T.: Kusunoki. H.: Sato. K.: Wakamatsu. K. J. Bionol. $M R R$ 1998. 12. 109-121.

21. Chae. Y. K.: Cho, K. S.; Chun, W: Lee, K. Protem Pept Lett 2003. $10,369-374$. 